\title{
Clinical trial on the effect of regular tea drinking on iron accumulation in genetic haemochromatosis
}

\author{
J P Kaltwasser, E Werner, K Schalk, C Hansen, R Gottschalk, C Seidl
}

Medizinische Klinik III, Zentrum der Inneren Medizin, der Johann Wolfgang Goethe-Universität, Theodor-Stern-Kai 7, D-60596 Frankfurt am Main, Germany

J P Kaltwasser

R Gottschalk

K Schalk

Institute of Radiation Protection,

GSF-National

Research Center for

Environment and

Health, Ingolstädter

Landstr. 1, D-85764

Oberschleipheim,

Germany

E Werner

C Hansen

Institut für

Transfusionsmedizin

und

Immunhämatologie

Blutspendedienst des

DRK Hessen,

Sandhofstrasse 1,

D-60528 Frankfurt am

Main

C Seidl

Correspondence to:

Professor J P Kaltwasser.

Accepted for publication 13 May 1998

\begin{abstract}
Background-Black tea is known to be a potent inhibitor of intestinal absorption of non-haem iron at least in healthy subjects. Aims-To investigate this effect in patients with genetic haemochromatosis, and, more importantly, the effect of regular tea drinking on the accumulation of storage iron in these patients over one year.

Patients-Investigations were carried out on 18 patients with clinically proven genetic haemochromatosis. For the study of storage iron accumulation, they were separated into a group instructed to drink a particularly tannin rich tea regularly with meals and a control group.

Methods-Intestinal iron absorption from a test meal was measured using whole body counting. Body iron stores were evaluated quantitatively by exhaustive phlebotomy, using haemoglobin, saturation of serum iron binding capacity, and serum ferritin for the assessment of body iron status.

Results-A significant reduction in iron absorption was observed when the test meal was accompanied by drinks of tea instead of water. In the tea drinking group, the increase in storage iron was reduced by about one third compared with that of the control group.

Conclusions-Regular tea drinking with meals reduces the frequency of phlebotomies required in the management of patients with haemochromatosis.

(Gut 1998;43:699-704)
\end{abstract}

Keywords: genetic haemochromatosis; iron absorption; tea; storage iron accumulation

Iron is one of the most important essential trace elements for human life. Although quite abundant in the environment, iron deficiency still remains one of the most common deficiency syndromes world wide, since the availability of iron for biological systems is limited. Therefore iron is spared within the human body, but there is no possibility of depleting surplus iron. Severe iron overload results in significant tissue damage, and even small amounts of excess iron may be harmful, leading to increased risk of cardiac infarction ${ }^{1}$ and malignancies. ${ }^{2}$

Effective removal of excess iron from the human body is achieved only by venesection or sophisticated chelation induced excretion. ${ }^{34}$ Since these procedures are rather cumbersome and invasive, patients with iron overload syndromes such as genetic haemochromatosis $(\mathrm{GH})$ or refractory anaemia are always looking for possibilities of reducing nutritional iron intake. An iron free diet is, however, not appropriate for long term use. Therefore, for such patients, reduced intestinal absorption of dietary iron would be beneficial.

Ligands known to inhibit iron absorption include phytates, tannates, phosphates, oxalates, and carbonates; of these, tannates are the most potent inhibitors of non-haem iron absorption..$^{5-9}$ Black tea represented by various brands is a foodstuff that is rich in tannates and is a popular beverage in many parts of the world. Although the inhibitory effect of tea drinking on iron absorption was recognised sometime ago, ${ }^{10-14}$ no clinical studies on its beneficial effect in the management of iron overload syndromes have until now been carried out.

In this study patients with proven $\mathrm{GH}$ were used to investigate the inhibitory effect of tea drinking on body iron accumulation under conditions of normal life. From 10 commercially available brands of tea, the one with the highest content of tannic acids when extracted for five minutes using boiling water was selected.

In the first part of the study, the effect of the selected brand of tea on intestinal iron absorption from a test meal was evaluated. In the second part, a controlled two armed study on the effect of regular tea drinking together with meals on iron accumulation in the body was carried out. Finally, the reaccumulation of storage iron over one year was assessed in tea drinkers as well as non-tea drinkers by exhaustive phlebotomy. The difference in storage iron between the two subgroups represented the inhibition of iron uptake from food caused by regular tea drinking.

\section{Materials and methods}

SUBJECTS

A total of 18 patients (17 men and one non-menstruating woman) with biopsy proven $\mathrm{GH}$ were included in the study (table 1). One man participated twice. HLA serotyping disclosed a combination of A3/B7 alleles in seven patients, A3 (blank) in another seven patients, and B7 (only) in one patient. Four patients showed neither of these haplotypes. At the beginning of the study, it was not yet possible to determine the recently reported $\mathrm{GH}$ related defective MHC class I (HLA-H) gene. ${ }^{15}$ However, we could determine the amino acid 


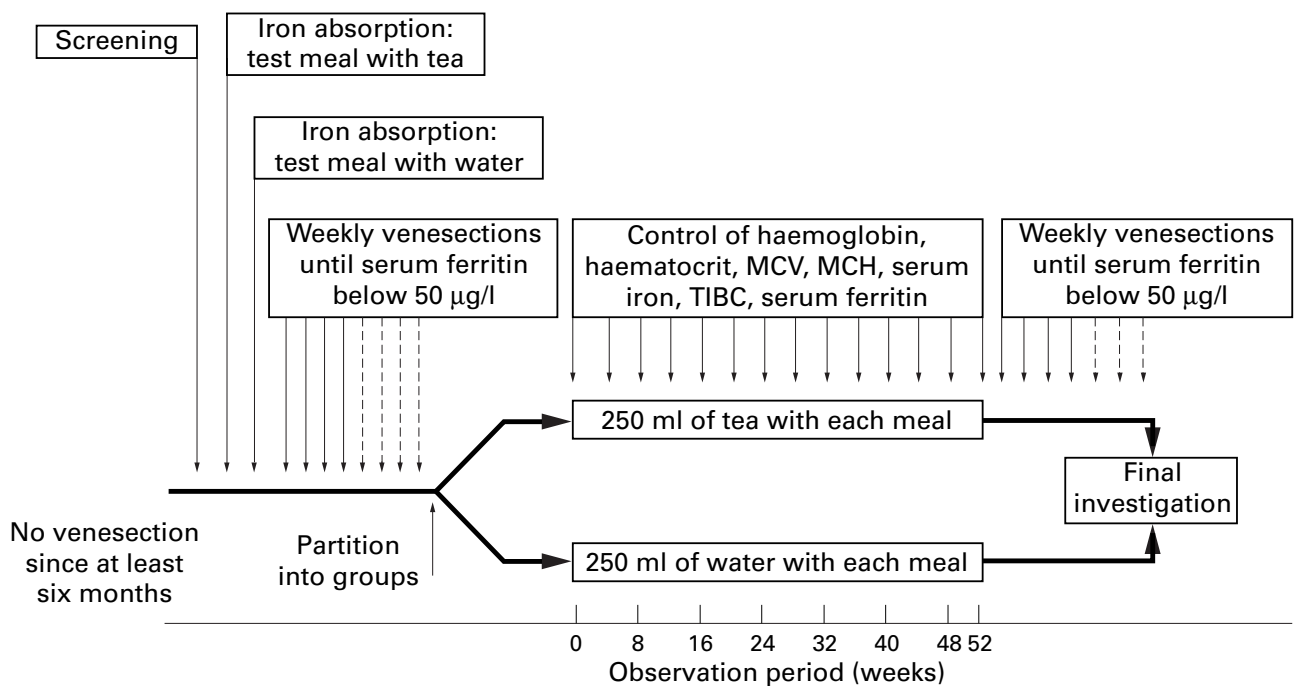

Figure 1 Outline of study design. MCV, mean cell volume; MCH, mean cell haemoglobin; TIBC, total iron binding capacity.

dimorphism at codon 63 (H63D) and codon $282(\mathrm{C} 282 \mathrm{Y})$ of the HFE gene in 10 of the 18 patients after termination of the study. The data show that all patients investigated were homozygous for the $\mathrm{C} 282 \mathrm{Y}$ mutation whereas none showed the H63D mutation. Mean age at the screening investigation (fig 1) was 46 (range 20-71) years. Mean (SEM) time since diagnosis of the disease was 5.4 (1.1) years. All patients had been followed since diagnosis regularly at least twice a year in our unit. These patients did not have any underlying malignancy, acute or chronic infection, or other major haemochromatosis unrelated disease.

All patients were informed in detail about the aims and requirements of the study and written consent was obtained from each. All patients completed the study. Baseline laboratory values are given in table 1 . Amounts of mobilised storage iron after diagnosis show distinct differences, possibly because of the state of inheritance and disease duration.

\section{STUDY DESIGN}

Figure 1 is an outline of the study. In all but two patients (1.9 and 2.5 in table 1 ), who had not previously been phlebotomised, the study was initiated at least six months after the last phlebotomy. After an initial assessment of body iron status, intestinal iron absorption from a test meal was measured twice consecutively, with and without tea to evaluate the intraindividual inhibitory effect of tea. Thereafter patients were phlebotomised until serum ferritin was decreased to less than $50 \mu \mathrm{g} / 1$ in order to achieve homogeneous low normal iron stores in all subjects.

Subsequently the patients were allocated according to their customs and wishes with regard to tea drinking into group 1, taking

Table 1 Patient characteristics at time of diagnosis and laboratory data at time of screening

\begin{tabular}{|c|c|c|c|c|c|c|c|c|c|c|c|c|c|c|}
\hline \multirow[b]{2}{*}{ Subject } & \multirow[b]{2}{*}{$\begin{array}{l}\text { Gender } \\
M / F\end{array}$} & \multicolumn{2}{|c|}{ Time of diagnosis } & \multirow[b]{2}{*}{$\begin{array}{l}\text { Age } \\
\text { (years) }\end{array}$} & \multicolumn{2}{|l|}{$H F E$} & \multicolumn{8}{|l|}{ Screening } \\
\hline & & $\begin{array}{l}\text { Age } \\
\text { (years) }\end{array}$ & $\begin{array}{l}\text { Mobilised } \\
\text { storage iron } \\
(\mathrm{g})\end{array}$ & & $C 282 Y$ & $H 63 D$ & $\begin{array}{l}\text { Haemoglobin } \\
(\mathrm{mmol} / \mathrm{l})\end{array}$ & $\begin{array}{l}\text { Serum iron } \\
(\mu \mathrm{mol} / \mathrm{l})\end{array}$ & $\begin{array}{l}\text { TIBC } \\
(\mu \mathrm{mol} / \mathrm{l})\end{array}$ & $\begin{array}{l}\text { Saturation } \\
\text { of TIBC } \\
(\%)\end{array}$ & $\begin{array}{l}\text { Serum } \\
\text { ferritin } \\
(\mu g / l)\end{array}$ & $\begin{array}{l}A S T \\
(U / l)\end{array}$ & $\begin{array}{l}A L T \\
(U / l)\end{array}$ & $\begin{array}{l}G G T \\
(U / l)\end{array}$ \\
\hline \multicolumn{15}{|c|}{ Tea group } \\
\hline 1.1 & $M$ & 19 & 4.2 & 29 & ND & & 10.6 & 35.6 & 39.2 & 91 & 119 & 8 & 7 & 5 \\
\hline 1.2 & M & 57 & 23.6 & 67 & ND & & 9.1 & 32.8 & 39.8 & 82 & 254 & 26 & 19 & 22 \\
\hline 1.3 & M & 36 & 20.8 & 46 & $+/+$ & $-1-$ & 11.0 & 42.3 & 45.0 & 94 & 189 & 27 & 29 & 10 \\
\hline 1.4 & M & 58 & 3.5 & 60 & ND & & 10.7 & 14.9 & 42.4 & 35 & 179 & 20 & 33 & 29 \\
\hline 1.5 & $M$ & 50 & 20.0 & 54 & ND & & 9.7 & 38.9 & 53.0 & 73 & 119 & 45 & 55 & - \\
\hline 1.6 & $M$ & 36 & - & 37 & ND & & 9.8 & 19.3 & 36.7 & 53 & 137 & 11.2 & 16 & 9.3 \\
\hline $1.7^{\star}$ & $M$ & 49 & 5.0 & 52 & $+/+$ & $-1-$ & 10.6 & 24.0 & 34.4 & 70 & 180 & 65 & 176 & 20 \\
\hline 1.8 & M & 42 & 4.8 & 47 & $+/+$ & $-1-$ & 11.7 & 47.3 & 49.9 & 95 & 61 & 27 & 60 & 37 \\
\hline 1.9 & $\mathrm{M}$ & 20 & 1.4 & 20 & ND & & 10.6 & 21.0 & 69.3 & 30 & 178 & 25 & 55 & 56 \\
\hline Mean & $9 M$ & 40.8 & 10.4 & 45.8 & & & 10.4 & 30.6 & 44.6 & 69 & 157 & 28 & 50 & 24 \\
\hline SEM & & 4.5 & 2.9 & 4.7 & & & 0.2 & 3.6 & 3.8 & 8 & 17 & 5 & 16 & 6 \\
\hline \multicolumn{15}{|c|}{ Water group } \\
\hline 2.1 & $M$ & 37 & 19.6 & 45 & ND & & 9.9 & 32.1 & 41.4 & 77 & 301 & 23 & 32 & 14 \\
\hline 2.2 & M & 19 & 4.4 & 26 & $+/+$ & $-1-$ & 9.2 & 21.5 & 42.2 & 47 & 110 & 10 & 12 & 9 \\
\hline 2.3 & $M$ & 27 & 4.6 & 29 & $+/+$ & $-1-$ & 9.9 & 15.9 & 38.1 & 42 & 151 & 27 & 61 & 12 \\
\hline 2.4 & $M$ & 39 & 15.0 & 47 & $+/+$ & $-1-$ & 10.1 & 30.1 & 43.5 & 69 & 192 & 19 & 13 & - \\
\hline 2.5 & $\mathrm{~F}$ & 71 & 2.4 & 71 & $+/+$ & $-1-$ & 9.9 & 35.1 & 41.4 & 85 & 600 & 20 & 37 & 12 \\
\hline 2.6 & M & 43 & 17.7 & 44 & $+/+$ & $-1-$ & 8.1 & 18.8 & 55.3 & 30 & 63 & 38 & 55 & 36 \\
\hline $2.7^{\star}$ & $M$ & 49 & 5.0 & 53 & $+/+$ & $-1-$ & 10.2 & 24.7 & 48.2 & 51 & 96 & 65 & 176 & 20 \\
\hline 2.8 & $M$ & 41 & 23.2 & 44 & $+/+$ & $-1-$ & 10.2 & 41.6 & 47.8 & 87 & 252 & 42 & 76 & 40 \\
\hline 2.9 & M & 39 & 17.1 & 45 & $+/+$ & $-1-$ & 10.0 & 28.7 & 37.3 & 77 & 180 & 39 & 58 & 19 \\
\hline 2.10 & $\mathrm{M}$ & 43 & 5.3 & 82 & ND & & 8.9 & 32.2 & 42.6 & 76 & 285 & - & 192 & - \\
\hline Mean & $1 \mathrm{~F} / 9 \mathrm{M}$ & 40.8 & 11.5 & 46.6 & & & 9.6 & 28.3 & 44.2 & 64 & 223 & 31 & 71 & 20 \\
\hline SEM & & 4.1 & 2.3 & 4.0 & & & 0.2 & 2.0 & 1.6 & 6 & 46 & 5 & 19 & 4 \\
\hline
\end{tabular}

*Patient participating twice.

TIBC, total iron binding capacity; AST, aspartate aminotransferase; ALT, alanine aminotransferase; GGT, $\gamma$-glutamyl transpeptidase; ND, not done. 


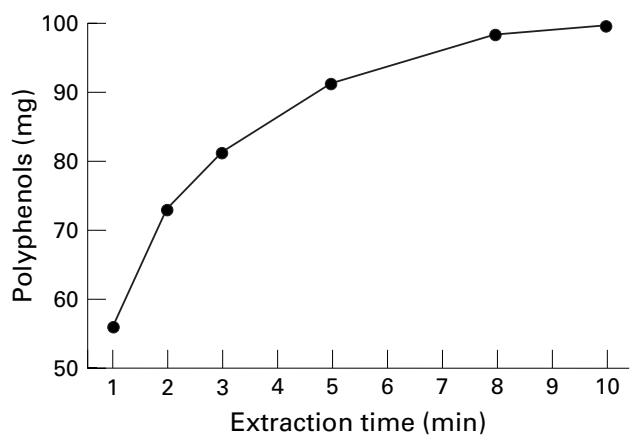

Figure 2 Time dependence of extraction of polyphenols from $1.5 \mathrm{~g}$ "Wewesse Ceylon Broken" tea with $250 \mathrm{ml}$ boiling water.

meals with tea, and group 2, having meals without drinking or with beverages other than tea. In addition, all patients were advised not to drink alcohol for at least one hour before until one hour after meals. To our knowledge, no patient with higher than normal alcohol consumption was included in the study. The assignment of the patients to the groups was consciously not randomised as, because of the long observation period, randomisation would probably have decreased patient compliance with the protocol. Although the distribution into the two groups was not random, the groups did not differ significantly in any variable at the beginning of the second part of the study (table 1). During the following 52 weeks, control measurements of haemoglobin, packed cell volume, mean cell volume, mean cell haemoglobin, serum iron concentration, total iron binding capacity (TIBC), saturation of TIBC, and serum ferritin concentration were performed every four weeks. Thereafter, iron stores accumulated during this period were evaluated by quantitative phlebotomy. ${ }^{16} 17$ One of the patients consecutively joined both groups (table $1 ; 1.7$ and 2.7 respectively).

SELECTION OF TEA BRAND

Ten brands of Indian and Ceylon tea were tested, from which was selected one of Ceylon origin that had the highest content of polyphenols ("Wewesse Ceylon Broken"). The total amount of polyphenols was determined by extraction of $1.5 \mathrm{~g}$ tea with $250 \mathrm{ml}$ boiling water by the methods of Schneider ${ }^{18}$ and Schorn. ${ }^{19}$ The amount of polyphenols extracted is a function of time (fig 2). After five minutes of extraction, about $90 \%$ of the polyphenols appear in the aqueous phase.

Patients in group 1 were advised to use $1.5 \mathrm{~g}$ of the selected tea, extracted for five minutes with $250 \mathrm{ml}$ boiling water, over the period of the investigation. They were instructed to drink the tea with meals three times a day without any additions such as lemon or milk.

\section{INTESTINAL IRON ABSORPTION}

Intestinal iron absorption from a test meal was measured by using a whole body counter with invariant response with respect to the distribution of radioactivity within the human body. ${ }^{20}$ The test meal was composed of beef, rice, spinach, and potatoes in a homogenised form.
The total mass of $190 \mathrm{~g}$ included $5.7 \mathrm{~g}$ protein, $5.7 \mathrm{~g}$ fat, and $11.4 \mathrm{~g}$ carbohydrate. The total iron content was $5.9 \mathrm{mg}$, of which $3.6 \mathrm{mg}$ was non-haem iron. Immediately before application, the test meal was labelled extrinsically with $30 \mathrm{kBq}{ }^{59} \mathrm{Fe}$ as citrate in sterile saline. ${ }^{21}$ The iron content of the extrinsic label was less than $1 \mu \mathrm{g}$. After careful mixing, the meal was eaten with a plastic spoon.

The test meal was given twice, in the morning after an overnight fast. Subjects continued fasting for at least two more hours. Measurements of total body radioactivity were carried out before the meal (individual background), after the meal and seven and 14 days later. On the first occasion, $200 \mathrm{ml}$ of the tea was given together with the meal, whereas on the second occasion-that is, two weeks later-the same volume of tap water was given with the meal. To keep the amount of radioactivity administered as low as possible, the order of the two consecutive absorption tests was not random. Because of the low iron content of the test meal and the time interval of two weeks between the two tests, any effect of the first absorption on the second test could be excluded. All measured count rates were corrected for individual background and for decay of radioactive iron to the time of application. During the second course, the count rates were also corrected for ${ }^{59} \mathrm{Fe}$ radioactivity remaining from the first absorption test. Percentage iron absorption (A) was calculated using the equation:

$$
A=\frac{Z_{14}-Z_{b}}{Z_{o}-Z_{b}} \times K_{14} \times 100 \%
$$

where $Z_{b}$ is individual background-that is, count rate of whole body $\gamma$ rays in energy band $1.00-1.45 \mathrm{MeV}$ before the test $-Z_{0}$ is the count rate after the meal, $Z_{14}$ is the count rate 14 days after the meal, and $k_{14}$ is the correction factor for radioactive decay of ${ }^{59} \mathrm{Fe}$ over 14 days - that is, 1.243 .

In addition, the ratio of count rates after seven days to that after 14 days $\left(\mathrm{V}_{14.7}\right)$ was calculated as follows:

$$
\mathrm{V}_{14.7}=\frac{\left(\mathrm{Z}_{14}-\mathrm{Z}_{\mathrm{b}}\right) \mathrm{k}_{14}}{\left(\mathrm{Z}_{7}-\mathrm{Z}_{\mathrm{b}}\right) \mathrm{k}_{7}}
$$

where $Z_{7}$ is the count rate seven days after the meal and $k_{7}$ is the correction factor for radioactive decay of ${ }^{59} \mathrm{Fe}$ over seven days - that is, 1.115 .

As shown previously, this factor is a useful tool for differentiating iron overload into primary and secondary forms, ${ }^{17}$ and it is an early indicator of altered intestinal iron absorption in subjects with genetic aberrations leading to haemochromatosis. ${ }^{1722}$

LABORATORY AND STATISTICAL METHODS Haemoglobin and the serum transaminases aspartate aminotransferase, alanine aminotransferase, and $\gamma$-glutamyl transpeptidase (GGT) were measured by standard methods. Serum iron, TIBC, and serum ferritin were measured as described by the International Committee on Standardisation in Hematology 
Table 2 Effect of tea on iron absorption and mucosal iron transfer $\left(V_{14.7}\right)$ in patients with genetic haemochromatosis

\begin{tabular}{|c|c|c|c|c|c|}
\hline \multirow[b]{2}{*}{ Subject } & \multicolumn{2}{|l|}{ Test meal with tea } & \multicolumn{2}{|c|}{ Test meal with water } & \multirow[b]{2}{*}{$\begin{array}{l}\text { Absorption ratio } \\
A_{\text {tea }} / A_{\text {zvater }}\end{array}$} \\
\hline & $\begin{array}{l}\text { Iron absorption } \\
(\%)\end{array}$ & $V_{14.7}$ & $\begin{array}{l}\text { Iron absorption } \\
(\%)\end{array}$ & $V_{14.7}$ & \\
\hline 1.1 & 7.0 & 1.03 & 13 & 0.84 & 0.53 \\
\hline 1.2 & 3.0 & 0.79 & 63 & 1.00 & 0.05 \\
\hline 1.3 & 19 & 1.02 & 45 & 1.00 & 0.42 \\
\hline 1.4 & 5.7 & 0.98 & 19 & 0.89 & 0.30 \\
\hline 1.5 & 7.4 & 0.85 & 16 & 0.94 & 0.46 \\
\hline 1.6 & 2.9 & 1.06 & 17 & 0.95 & 0.15 \\
\hline 1.7 & 2.7 & 0.81 & 14 & 0.83 & 0.19 \\
\hline 1.8 & 1.9 & 0.90 & 12 & 1.07 & 0.15 \\
\hline 1.9 & 0.8 & 0.70 & 5.7 & 0.79 & 0.14 \\
\hline 2.1 & 19 & 0.99 & 32 & 1.04 & 0.59 \\
\hline 2.2 & 3.9 & 1.04 & 21 & 1.01 & 0.19 \\
\hline 2.3 & 1.0 & 1.08 & 8 & 0.91 & 0.12 \\
\hline 2.4 & 6.7 & 0.96 & 12 & 0.98 & 0.57 \\
\hline 2.5 & 0.4 & ND & 4.8 & 0.78 & 0.08 \\
\hline 2.6 & 10 & 1.01 & 29 & 1.00 & 0.34 \\
\hline 2.8 & 9.5 & 1.00 & 33 & 1.02 & 0.29 \\
\hline 2.9 & 20 & 1.05 & 37 & 1.02 & 0.54 \\
\hline 2.10 & 3.4 & 1.05 & 16 & 0.92 & 0.21 \\
\hline Mean & 6.9 & 0.96 & 22.1 & 0.94 & 0.30 \\
\hline SEM & 1.4 & 0.03 & 3.4 & 0.02 & 0.04 \\
\hline
\end{tabular}

ND, not done.
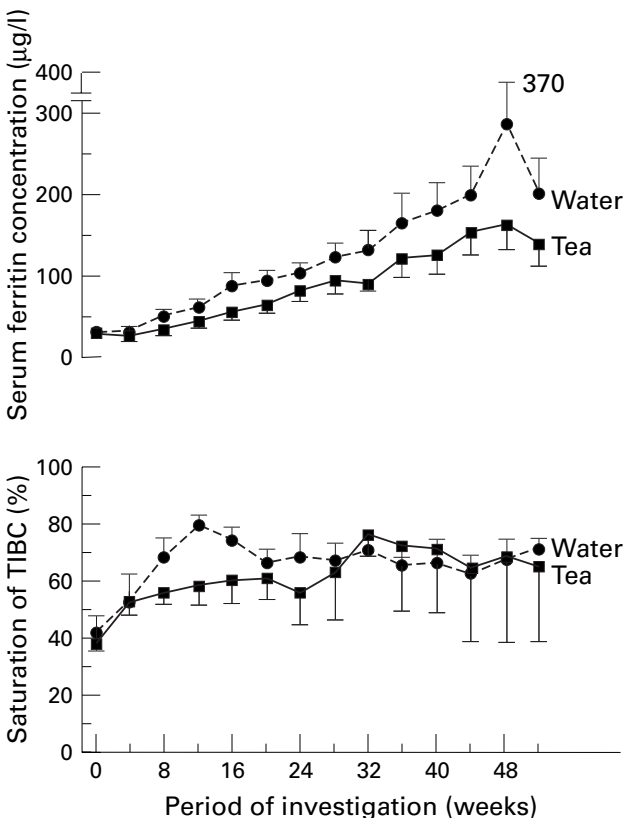

(ICSH). ${ }^{23-25}$ Table 1 gives patient and laboratory characteristics at the beginning of the study.

Genomic DNA was extracted from whole blood samples anticoagulated with EDTA by the salting out procedure. The amino acid dimorphism at codon 63 (H63D) and codon 282 (C282Y) of the HFE gene was defined by polymerase chain reaction (PCR) amplification of genomic DNA samples followed by restriction enzyme digestion as described elsewhere. ${ }^{26}$ The H63D dimorphism was analysed with $B c l$ I and $M b o I$, and the C282Y dimorphism with RsaI and SnaBI. Restriction enzymes were used as recommended by the manufacturer (Stragene $\mathrm{GmbH}$, Heidelberg, Germany) at a concentration of $4 \mathrm{U} / \mu \mathrm{g}$ DNA for 10 hours in a final reaction volume of $20 \mu \mathrm{l}$. Products were separated by standard gel electrophoresis using 3\% NuSieve $1 \%$ agarose (Agarose NA; Pharmacia Biotech, Uppsala, Sweden; NuSieve GTGagarose; FMC Bioproducts, Rockland, Maine, USA) for one hour at $100 \mathrm{~V}$. Gels were stained with ethidium bromide $(0.5 \mu \mathrm{g} / \mathrm{ml})$.

Standard statistical methods were used to calculate mean (SEM) values. Mean values were compared by Student's $t$ test. After exhaustive phlebotomy, a linear increase in serum ferritin over time was assumed for the patients with haemochromatosis. Linear regression analysis was carried out by the method of least squares, and correlation coefficients were tested for statistical significance as described by Bravais and Pearson in ref 27 . Regression coefficients were compared using Student's $t$ test. ${ }^{27}$

Results

Table 2 gives the results of the radioactive iron absorption tests. The individual fractions of iron absorption from the test meal show considerable variations. However, in each patient the absorption was reduced when the test meal was given together with tea. On average, intestinal iron absorption was reduced from 22.1 to $6.9 \%$ by the addition of tea com-
Figure 3 Time course of serum ferritin concentration and saturation of total iron binding capacity (TIBC) (means (SEM)) in patients with genetic haemochromatosis during one year without phlebotomy treatment.

pared with water- that is, a reduction of about $70 \%(\mathrm{p}<0.001)$.

In contrast, mucosal iron transfer $\left(\mathrm{V}_{14.7}\right)$ was unaffected by tea. On both occasions the mean values of $\mathrm{V}_{14.7}$ were significantly increased $(0.96$ (0.03) and $0.94(0.02)$ ). Normal healthy non-menstruating adults have been reported to have a $V_{14.7}$ value of $0.58(0.02) .{ }^{17}{ }^{28}$ The differences are statistically different $(p<0.001)$.

According to the study regimen, at the beginning of the observation period (fig 1) both groups showed comparable mean values of serum iron and TIBC in the normal range (tea group: $15.4(1.4)$ and $45.3(3.9) \mu \mathrm{mol} / 1$; control group: 19.9 (2.9) and $47.5(1.3) \mu \mathrm{mol} /$ 1). Mean levels of serum ferritin were 27 (3) $\mu \mathrm{g} / 1$ in the tea group and 35 (4) $\mu \mathrm{g} / 1$ in the control group. In all patients haemoglobin values were within the normal range and remained almost unchanged during the whole observation period.

Figure 3 shows the changes in saturation of TIBC and serum ferritin concentration during the observation period. Saturation of TIBC showed an increase in both groups after four weeks. Thereafter the increase in the control group was much more pronounced than in the tea drinking group. However, after one year both groups ended up with almost the same increased level of TIBC saturation. There was a difference in the increase in serum ferritin concentration between the two groups. Applying linear regression analysis, the increase in serum ferritin per week for the tea drinking group is given by $\mathrm{Fn}=2.78(\mathrm{t}+14)(r=0.98$; $\mathrm{p}<0.001)$ and for the control group $\mathrm{Fn}=$ $4.26(t+13)(r=0.95 ; p<0.001)$, where Fn is serum ferritin concentration $(\mu \mathrm{g} / \mathrm{l})$ and $\mathrm{t}$ is observation time (0 to 52 weeks).

The iron mobilised during the venesections ${ }^{17}$ (106) $\mathrm{mg}$ in the tea drinking group and 1436 after the observation period (fig 1) was 1085 


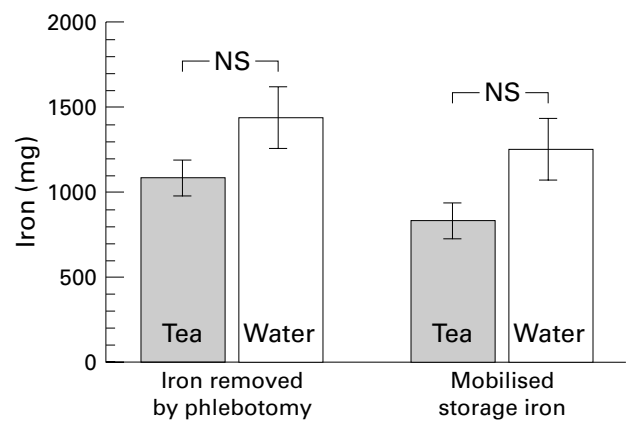

Figure 4 Storage iron accumulated over one year. Columns on the left show the amount of iron removed by phlebotomy in the tea drinking and control groups at the end of the observation period; columns on the right show mobilised storage iron, calculated as iron removed by phlebotomy corrected for iron absorbed during the time course of the phlebotomies (see the text). The differences between the tea and water drinking groups are statistically not significant $(t=1.63$ and $2.04 ; p<0.05$ would require 2.12).

(178) $\mathrm{mg}$ in the control group (fig 4). When corrected for intestinal food iron absorption during the second venesection period, ${ }^{17}$ the values for reaccumulated storage iron within the observation period of 52 weeks were 827 (105) $\mathrm{mg}$ in the tea drinking group and 1256 (173) $\mathrm{mg}$ in the control group (fig 4). Although the level of iron accumulation was about $50 \%$ higher in the control group than the tea drinking group, the difference did not reach statistical significance.

\section{Discussion}

The inhibitory effect of tannates of vegetable origin on intestinal iron absorption has been shown in various studies. ${ }^{69}$ Black tea in particular, a commonly used beverage, has been shown by Disler ${ }^{10}$ and others ${ }^{71-13}$ to reduce the uptake of iron from various sources of inorganic iron by about two thirds as compared with water intake.

In this study we confirmed the inhibitory effect of black tea on intestinal iron absorption in patients with genetic haemochromatosis. All previous studies were carried out on healthy subjects or patients with refractory anaemia. To our knowledge no studies on patients with $\mathrm{GH}$ have so far been published. At the beginning of this study, all patients clinically manifested iron overload. The state of inheritance (homozygosity/heterozygosity) was investigated by pedigree analysis whenever possible. Thus subjects 1.2 and 1.1 and 2.8 and 1.9 are fathers and sons, and 2.5 and 2.6 are mother and son respectively. All ten patients who could be investigated for the HFE gene, available for determination only after termination of the study, were homozygous for the C282Y mutation. In addition, in all subjects the clinical expression of the gene defect could be shown by an increase in $\mathrm{V}_{14.7}$ at the beginning of the study (table 2). These findings are supported by the amount of increased mobilisable storage iron at the time of diagnosis (table 1), as well as by the reaccumulation of storage iron during the observation period, especially in those patients who did not drink tea (fig 4).

The brand of tea used in the study was selected for the highest tannin content possi- ble. To help patients comply with the protocol of the long term study, preparation time did not exceed common practice. In addition, the taste of the tea was made as acceptable and pleasant as possible. According to German custom, a Ceylon brand (a particular sort of "Wewesse Ceylon Broken") and five minutes extraction time were recommended to the patients. As shown in fig 1, a five minute preparation time results in about $90 \%$ yield of the extractable polyphenols. This protocol was well accepted by the participants, and all patients assigned to the tea drinking group were happy to continue with tea drinking during meals after termination of the study.

The significant inhibitory effect of tea on iron absorption, as shown in table 2 , is in broad agreement with data from other investigations. ${ }^{7101113}$ There is evidence that the polyphenol content of tea or other food is a major determinant of the inhibitory effect on non-haem iron absorption. ${ }^{9}{ }^{29}$ This agrees with the observation that the inhibitory effect is seen only with black tea and not with Japanese green tea. ${ }^{30}$

Polyphenols are assumed to act by binding heavy metals in the gastrointestinal lumen. ${ }^{31}$ This is confirmed by our study, as we showed that, despite the significant reduction in iron absorption, mucosal transfer remained unchanged. The values for $\mathrm{V}_{14.7}$ remained the same (table 2) whether the test meal was given with or without tea. The increase in mucosal transfer $\left(\mathrm{V}_{14.7}\right)$ over that in healthy subjects shows that the defect in iron absorption due to haemochromatosis is still present. Consequently, the observed reduction in iron absorption caused by tea in haemochromatosis can be attributed to luminal binding of iron to the polyphenols.

Because of the ability of polyphenols in black tea to convert dietary non-haem iron into a form unavailable for absorption, it seems reasonable to utilise this common beverage to reduce iron uptake and accumulation in iron overload syndromes, as has already been suggested by De Alarcon et al. ${ }^{11}$ Whereas the inhibitory effect of tea on non-haem iron absorption has clearly been shown in single dose experiments, the prolonged action on iron balance with respect to the frequency of iron deficiency has so far only been investigated in healthy infants. ${ }^{32}$ In our study, the effect of regular tea drinking during meals on accumulation of storage iron in patients with $\mathrm{GH}$ was studied.

The drinking of tea with main meals is not common in Germany. Therefore the study patients were carefully advised on how to prepare and use the selected brand of tea. Since iron accumulation in patients with $\mathrm{GH}$ is a slow but perpetual process, the effect of tea on accumulation of storage iron was investigated by a controlled prospective study carried out for a period of one year. The initial iron status of both groups (tea and non-tea drinkers) was comparable (table 1). As a result of the venesections performed between the two iron absorption tests and the beginning of the 
observation period (fig 1), the body iron status of all patients was low normal.

As could be expected, haemoglobin concentrations were almost constant throughout the study. Saturation of TIBC showed an early increase during the first three months in the control group, as is usually observed in the post-phlebotomy phase ${ }^{33}$ (fig 3 ). In contrast, in the tea drinking group, there was a much slower increase in iron saturation of TIBC during the first six months of the study (fig 3).

In the second half of the study course, mean values of saturation of TIBC for the two groups were mostly identical at a level exceeding $60 \%$-that is, an increase in storage iron could be predicted for both groups. In fact, serum ferritin, measured as a non-invasive index of iron stores, showed an increase in both groups, but the slope was different (fig 3). From the slope factors of the above calculated regression functions, it could be concluded that the mean increase in serum ferritin in the control group is about $50 \%$ higher than in the tea drinking group. Assuming a relation between serum ferritin and amount of storage iron of $8 \mathrm{mg} \mathrm{Fe}$ per $\mu \mathrm{g} / \mathrm{l}$ serum ferritin, ${ }^{28}{ }^{34}$ for the control group a storage iron increase of $145 \mathrm{mg} \mathrm{Fe}$ per month and in the tea drinking group of $97 \mathrm{mg} \mathrm{Fe}$ per month could be calculated. However, the repeat phlebotomy showed a mean increase in mobilised storage iron of only 105 and $69 \mathrm{mg}$ per month for the control and tea drinking group respectively (fig 4). This difference between calculated and observed increase in storage iron may be partly due to a change in the assumed storage iron to serum ferritin ratio in iron overloaded patients. ${ }^{17}$

CONCLUSIONS

From the data presented it is evident that regular tea drinking with meals reduces storage iron reaccumulation in patients with genetic haemochromatosis, but to a smaller extent than could be expected from studies on single doses. Statistical significance was not reached in this study. Nevertheless, drinking of tea with meals can be recommended as an additional therapeutic tool for the maintenance of normal body iron status in pretreated genetic haemochromatosis. It should, however, be remembered that, even with regular tea drinking, phlebotomies are still required, but with reduced frequency.

The use of higher doses of polyphenolic compounds than those used in this study is possible, but the usefulness of this approach may be limited by side effects and also taste, reducing patient compliance with the recommended regimen - that is, lifelong daily use.

The authors wish to thank Professor H Glasl, Institut für Pharmakognostik, Johann Wolfgang Goethe-Universität Frankfurt makognostik, Johann Wolfgang Goethe-Universität Frankfurt for determination of the polyphenol content of the different
brands of tea. The valuable technical assistance of Mrs U Tacke, brands of tea. The valuable technical assistance of Mrs U Tacke,
Mrs H Hahn, and Mrs A Huck is appreciated. The authors are Mrs H Hahn, and Mrs A Huck is appreciated. The authors are
also indebted to Dr J Atta and Dr G Seipelt for their help in the also indebted to Dr J Atta and
preparation of the manuscript.

1 Salonen JT, Nyyssönen K, Korpela H, et al. High stored iron levels are associated with excess risk of myocardial infarction in eastern Finnish men. Circulation 1992;86:80311.
2 Stevens RG, Jones Y, Micozzi MS, et al. Body iron stores and the risk of cancer. N Engl f Med 1988;319:1047-52.

3 Pippard MJ. Desferrioxamine-induced iron excretion in humans. In: Hershko C, ed. Baillière's clinical haematology. London, Philadelphia, Sydney, Tokyo, Toronto: Baillière Tindall, 1989;2:323-44.

4 Hoffbrand AV, Wonke B. Results of long-term subcutaneous desferrioxamine therapy. In: Hershko C, ed. Baillière's clinical haematology. London, Philadelphia, Sydney, Tokyo, Toronto: Baillière Tindall, 1989;2:345-62.

5 Sharpe LM, Peacock WC, Cook R, et al. The effect of phytate and other food factors on iron absorption. $\mathrm{F}$ Nutr 1950;41:433-46

6 Gillooly M, Bothwell TH, Charlton RW, et al. Factors affecting the absorption of iron from cereals. $\mathrm{Br} \mathcal{F}$ Nutr 1984;51:37-46.

7 Brune M, Rossander L, Hallberg L. Iron absorption and phenolic compounds: importance of different phenolic structures. Eur F Clin Nutr 1989;43:547-58.

8 Cook JD, Morck TA, Lynch SR. The inhibitory effect of soy products on nonheme iron absorption in man. Am f Clin Nutr 1981;34:2622-9.

9 Tuntawiroon M, Sritongkul N, Brune M, et al. Dosedependent inhibitory effect of phenolic compounds in foods on non haem iron absorption in men. Am $\mathcal{F}$ Clin Nutr 1991;53:554-7.

10 Disler PB, Lynch SR, Charlton RW, et al. The effect of tea on iron absorption. Gut 1975;16:193-200.

11 De Alarcon PA, Donovan ME, Forbes GB, et al. Iron absorption in the thalassemia syndromes and its inhibition by tea. $N$ Engl f Med 1979;300:5-8.

12 Hallberg L, Rossander L. Effect of different drinks on the absorption of non-heme iron from composite meals. Hum Nutr 1982; 36A:116-23.

13 Morck, TA, Lynch SR, Cook JD. Inhibition of food iron absorption by coffee. Am F Clin Nutr 1983;37:416-20

14 Gabrielli,GB, De Sandre G. Excessive tea consumption can inhibit the efficacy of oral iron treatment in iron deficiency anemia. Haematologica 1995;80:518-20.

15 Feder JN, Gnirke A, Thomas W, et al. A novel MHC class I-like gene is mutated in patients with hereditary haemochromatosis. Nat Genet 1996;13:399-408.

16 Haskins D, Stevens, AR, Finch S, et al. Iron metabolism. Iron stores in man as measured by phlebotomy. 7 Clin Invest 1952;31:543-7.

17 Kaltwasser JP, Werner E. Diagnosis and clinical evaluation of iron overload. In: Hershko C, ed. Baillière's clinical haematology. London, Philadelphia, Sydney, Tokyo, Toronto: Baillière Tindall, 1989;2:363-90.

18 Schneider G. Zur Bestimmung der Gerbstoffe mit Casein. Arch Pharm (Weinheim) 1975;309:38-44.

19 Schorn PJ. Ratahiae Radix. Pharmacopoela Europaeica 1979; 2:1114-18.

20 Werner E, Morsy SM, Stahlhofen W, et al. A whole-body counter with invariant response. In: International Atomic Energy Agency, ed. Diagnosis and treatment of incorporated radionuclides. Vienna: International Atomic Energy Agency, 1976:231-5.

21 Cook JD, Layrisse M, Martinez-Torres C, et al. Food iron absorption measured by an intrinsic tag. F Clin Invest 1972; 51:805-15.

22 Kaltwasser JP, Werner E, Becker HJ. Therapie der Hämochromatose. Therapiewoche 1976;26:625-35.

23 ICSH. The measurement of total and unsaturated iron binding capacity in serum. Br f Haematol 1978;38:281-90.

$24 \mathrm{ICSH}$. Recommendations for the measurement of serum iron in human blood. Br f Haematol 1978;38:291-94.

25 Worwood M, Thorpe SJ, Haeth A, et al. Stable lyophilized reagent for the serum ferritin assay. Clin Lab Haematol 1991;13:297-305.

26 Roberts AG, Whatley SD, Morgan RR, et al. Increased frequency of the haemochromatosis C282Y mutation in sporadic porphyria cutanea tarda. Lancet 1997;349:321-3.

27 Sachs L. Statistische Auswertungsmethoden. Berlin, Heidelberg, New York: Springer Verlag, 1972.

28 Werner E, Kaltwasser JP, Bechstein PB. Untersuchungen zur Regulation des Eisenhaushalts. In: Oeff K, Schmidt HAE, eds. Nuklearmedizin, Nuklearmedizin und Biokybernetik. Berlin: Medico Informationsdienste, 1978;2:122-5.

29 Hallberg L, Brune M, Rossander-Hulten L. Iron absorption. In: Hercberg S, Galan P, Dupin H, eds. Aspects actuels des carence en fer et en folates dans le monde. Paris: INSERM, 1990:235-45.

30 Kubota K, Sakurai T, Nakazato K, et al. Effect of green tea on iron absorption in elderly patients with iron deficiency anemia. [English abstract]. fapanese fournal of Geriatrics 1990;27:555-8.

31 Disler PB, Lynch SR, Torrance JD, et al. The mechanism of the inhibition of iron absorption by tea. South African fournal of Medical Science 1975;40:109-16.

32 Merhav $\mathrm{H}$, Amitai Y, Palti $\mathrm{H}$, et al. Tea drinking and microcytic anemia in infants. Am f Clin Nutr 1985;41:1210-13.

33 Powell LW, Halliday JW. Idiopathic haemochromatosis. In: Jacobs A, Worwood M, eds. Iron biochemistry and medicine. London, New York: Academic Press, 1980;2:461-98.

34 Kaltwasser JP. Serumferritin bei Eisenüberladung. Folia Haematologica 1987;114:319-37. 